\title{
Pengenalan Bulliying dan Dampaknya Pada Pelaku dan Korban
}

\author{
EtyNurhayaty 1 \\ Universitas Bina Sarana Informatika, ety.eyy@bsi.ac.id \\ Ade Sri Mulyani ${ }^{2}$ \\ Universitas Bina Sarana Informatika, ade.aml@bsi.ac.id
}

\begin{abstract}
Abstrak
Akhir-akhir ini, kita di kejutkan kembali dengan maraknya fenomena bullying, baik yangdilakukan di lingkungan masyarakat maupun di lingkungan sekolah, dimana nampaknya para pelaku ini menikmati tindakannya, yang dibuktikan dengan proses perekaman yang seolah-olah kondisinya telah direncanakan dengan baik.Tanpa mereka sadari, bahwa perilaku bullying dapat memberikan dampak jangka pendek dan juga jangka panjang, khususnya bagi korban bully.Risiko yang paling berat adalah jika perilaku bully ini menimpa anak-anak, karena mereka akan lebih berisiko mengalami berbagai masalahkesehatan, baik secara fisik maupun mental seperti kegelisahan, depresi yang mungkin akan sulit dilupakan sampai mereka dewasa bahkan yang lebih dikhawatirkan adalah tak jarang mereka yang awalnya adalahkorban, suatu saat bisa menjadi pelaku, sehingga memiliki efek berantai yang sulit terputus. Kegiatan Pengabdian Masyarakat inidilakukan dengan metode ceramah, diskusi dan tanya jawab. Kegiatan ini dimulai dari mencari permasalahan yang umumnya terjadi dikalangan peserta, didiskusikan kemudian dirangkai menjadi solusi.Permasalahan peserta didapat pada saat diskusi kemudian pemecahan masalahdisajikan pada akhir kegiatan. Hasil kegiatan ini menunjukkan peserta sudah pahamakan makna dari bullying, dan dampaknya bagi pelaku maupun korban, sehinggamereka berusaha untuk tidak melakukannya baik terhadap teman disekolah, di rumah maupun dilingkungan masyarakat.
\end{abstract}

Kata Kunci: bullying, korban, bully.

\begin{abstract}
Lately, we are surprised again by the rampant phenomenon of bullying, both carried out in the community and in the school environment, where these actors seem to enjoy their actions, as evidenced by the recording process as if the conditions were well planned. Without them knowing that bullying can have a short-term and long-term impact, especially for victims of bullying. The most severe risk is if this bully befalls children, because they will be more at risk of experiencing various health problems, both physically and mentally such as anxiety, depression that may be difficult to forget until they are adults even more worrying is that they are not uncommon initially a victim, one day could be a perpetrator, so it has a chain effect that is difficult to break.Community Service Activities are carried out using lecture, discussion and question and answer methods. This activity starts from looking for problems that generally occur among the participants, discussed and then assembled into a solutionThe participants' problems are obtained during the discussion then problem solvingpresented at the end of the activity. The results of this activity indicate that participants have understood
\end{abstract}


the meaning of bullying, and its impact on the perpetrators and victims, so they try not to do this either to friends at school, at home or in the community.

Keywords: bullying, victim, bully.

\section{Pendahuluan}

Kegiatan pengabdian kepada masyarakat inidilatarbelakangi oleh maraknya aktifitas bullying yang terjadi di masyarakat, takterkecuali dalam lingkungan pendidikan. Menurut (Yuyarti, 2018) dalam jurnalnya mengatakan bahwa bulliying merupakan suatu bentuk kekerasan anak (child abuse) yang bisa dilakukan teman sebaya kepada seseorang (anak) yang lebih 'rendah' atau lebih lemah baik dari sisi fisik ataupun kemampuan untuk mendapatkan keuntungan atau kepuasan tertentu.

Bahkan Barbara Coloroso dalam (Yuyarti, 2018) menyatakan bahwa aktifitas bullying merupakan tindakan bermusuhan yang dilakukan secara sadar dan disengaja yang bertujuan untuk meyakiti orang lain, seperti menakuti melalui ancaman agresi dan menimbulkan teror. Termasuk juga tindakan yang direncanakan maupun yang spontan bersifat nyata atau hampir tidak terlihat, dihadapan seseorang dibalik persahabatan,dilakukan olehseseorang anak atau kelompok anak. Dari pengertian diatas dapat disimpulkan bahwa bullying ini adalah tindakan yang secara sadar ataupun tidak, merugikan orang lain baik secara fisik seperti menendang, memukul, menggigit, mencubit maupun secara mental.

Barbara Coloroso (Sari \& Azwar, 2018)telah membagi jenis-jenis bullying menjadi empat bagian, yaitu;

pertama, bullying verbal, dimana perilaku ini dapat berupa memanggil julukan nama yang biasanya tidak disukai, celaan, fitnah, kritikan kejam, penghinaan, pernyataanpernyataan yang bernuansa ajakan seksual atau pelecehan seksual, teror, surat-surat yang mengintimidasi, tuduhan-tuduhan yang tidak benar, kasak-kusuk yang keji dan keliru, gosip dan sebagainya.

Kedua, bullying fisik, yaitu yang secara langsung melukai fisik seseorang seperti memukul, mencubit, menendang, menampar, mencekik, menggigit, mencakar, meludahi, dan merusak serta menghancurkan barang-barang milik anak yang tertindas. Kendati bullying jenis ini adalah yang paling tampak dan mudah untuk diidentifikasi, namun kejadian bullying secara fisik tidak sebanyak bullying dalam bentuk lain, karena aktifitasnya yang mencolok. Orang yang secara teratur melakukan bullying dalam bentuk fisik, biasanya adalah orang yang paling bermasalah dan cenderung akan beralih pada tindakan-tindakan kriminal yang lebih lanjut.

Ketiga, bullying secara relasional, yaitu adalah pelemahan harga diri korban secara sistematis melalui pengabaian, pengucilan atau penghindaran. Perilaku ini dapat mencakup sikap-sikap yang tersembunyi atau berbentuk gesture tubuh seperti pandangan tajam, lirikan mata, helaan nafas, cibiran, tawa mengejek dan bahasa tubuh lainnya yang mengejek. Bullying dalam bentuk relasional ini merupakan perilaku bullying yang paling sulit dideteksi dari luar. Bullying secara relasional mencapai banyak terjadi di awal masa remaja, karena saat itu tejadi perubahan fisik, 
mental, emosional dan seksual remaja. Ini adalah saat ketika remaja mencoba untuk mengetahui diri mereka dan menyesuaikan diri dengan teman sebaya.

Keempat, bullying elektronik, ini adalah bentuk perilaku bullying yang dilakukan melalui sarana elektronik yang ada, seperti sosial media, komputer, handphone, internet, website, chatting, e-mail, SMS dan sebagainya. Biasanya ditujukan untuk meneror dan menyinggung korban dengan menggunakan tulisan, animasi, meme, gambar dan rekaman video atau film yang sifatnya mengintimidasi, menyakiti atau menyudutkan. Bullying elektronik biasanya dilakukan oleh kelompok remaja atau orang dewasa, atau siapa saja yang pada dasarnya telah memiliki pemahaman cukup baik terhadap sarana teknologi informasi dan media elektronik lainnya.

Dari keempat jenis bullying, bullying dalam bentuk verbal adalah salah satu jenis yang paling mudah dilakukan dan bullying bentuk verbal akan menjadi awal dari perilaku bullying yang lainnya serta dapat menjadi langkah pertama menuju pada kekerasan yang lebih lanjut

Adapun dampak dari bullying menurut Priatna dalam (Shidiqi \& Suprapti, 2013)yaitu kecemasan, depresi, penarikan sosial, merasa kesepian, dapat menyebabkan bunuh diri, penurunan prestasi akademik, serta penggunaan obatobatan terlarang dan alkohol.

Sebenarnya bullying ini dapat terjadi dimana saja, selama terdapat beberapa orang atau kumpulan orang, bullying akan terjadi baik disadari atau tidak. Termasuk di sekolah dan juga panti asuhan. Menurut Dinas sosial dalam (Sandri, 2015)Walaupun panti asuhan berperan sebagai pengganti orang tua, tetap saja ada beberapa hal yang berbedadengan keluarga. Perbedaan itu adalahjumlah anggota keluarga yang besar dantidak memiliki hubungan darah. Jumlahpengasuh yang berperan sebagai orangtua tidak sebanding dengan jumlah"anak"nya,Dengan demikianmengakibatkan kualitas perhatian akanberkurang karena banyaknya anak yangharus diperhatikan, selain itu pola asuh yang cenderung otoriter dan penerapandisiplin yang keras, menyebabkan anak kurang dapat berekspresi, setiap anak diperlakukan sama, , kebutuhan khususnya sebagai individu yang unik kurang diperhatikan, sehingga menurut Makame dalam (Sandri, 2015)banyak anak-anak yang tinggal di panti asuhantidak berfungsi sebaik yang diharapkanwalaupun kebutuhan materi mereka tercukupi.

Dari pengamatan penulis, pelaku dan korban bullying lebih banyak terjadi di kalangan anak-anak, yang mulanya secara tidak sengaja mereka lakukan di lingkungan sekolah dan rumah yang umumnya dilakukan oleh pihak yang merasa berkuasa, kuat dan atau mempunyai kelebihan tertentu. Hal ini sesuai dengan yang diungkapkan oleh Caroll et all dalam (zakiyah et al., 2017) yang menyatakan bahwa salahsatu faktor yang mempengaruhi remaja melakukan bulling adalah lemahnya ketrampilan sosial bully karena rasa simpati dan empati yang rendah dan memiliki tabiat menindas. Sedangkan berdasarkan hasil penelitian C. Samivalli dalam ( (Sandri, 2015) ) menyatakan bahwa motif sebagian dari para pelaku bullying adalah untuk mendapatkan pengakuan dari para korbannya, oleh karena itu dapat dipahami jika individu 
yang memiliki harga diri rendah, rentan menjadi pelaku bullying. Hal ini sangat bisa dipahami karena ketika seseorang menganggap dirinya tidak berharga dan tidak menyayangi dirinya sendiri, maka seseorang dapat melakukan beragam tindakan yang justru merugikan dirinya sendiri, baik disadarinya maupun tidak

Secara umum kegiatan sosialisasi bullying dalam kegiatan pengabdian masyarakat ini bertujuan untuk meningkatkan pengetahuan peserta tentang pengetahuan dasar bullying dan dampaknya terhadap pelaku dan korbannya.

Secara spesifik tujuan kegiatan ini sebagai berikut.

a. Memberikan pengetahuan dasar tentang bullying,

b. Memberikan pengetahuantentang macam-macam bullying

c. Memberikan pengetahuan cara menanganikasus bullying.

d. Memberikan pengetahuan tentang penyebab bullying dari sisipelaku dan korban

e. Memberikan pengetahuan tentang cara mengatasi bullying

f. Mengajak peserta untuk saling menghormati teman, guru dan masyarakat padaumumnya .

Adapun manfaat kegiatan pengabdian pada masyarakat ini adalah memberikan kontribusi positif dalam peningkatan pengetahuan peserta, diantaranya adalah:

a. Peserta memperoleh tambahan wawasan tentang bullying

b. Peserta dapat mempraktekkan dalam kehidupan sehari-hari, sehingga terciptasuasana yang aman dan tentram khususnya dilingkungan tempat peserta berada.

\section{Metode}

Metode kegiatan ini dilakukan dengan metode ceramah,diskusi dan tanya jawab. Pendekatan dilakukan dengan mencari/menggali permasalahanpeserta dan memberi solusi. Kegiatan dimulai dengan ceramah hal-hal penting terkait bullying, jenis-jenis bullying, dampak dan cara menanggulangi jika terjadi bullying di sekitar ditambah dengan pemutaran video yang terkait dengan edukasi bullying. Permasalahan peserta diketahui ketika proses tanya jawab. Dari permasalahan yang muncul disusun hal-hal penting untuk kemudian diberikan solusi pada akhir acara.

\section{Hasil dan Pembahasan}

Kegiatan PKM ini dilaksanakandalam bentuk ceramah, diskusi dan tanya jawab terprogram. Rincian kegiatan diperlihatkan dalam tabel 1 di bawah ini.

Tabel 1. Rincian Kegiatan Sosialisasi pada siswa

\begin{tabular}{ll}
\hline \multicolumn{1}{c}{ Jadwal } & \multicolumn{1}{c}{ Kegiatan } \\
\hline Sesi 1 & Pembukaan \\
$08.00-08.30$ & Sosialisasi pengertian bully dan jenis bullying \\
\hline Sesi 2 & \\
$08.30-09.00$ & Pemutaran video bully \\
$09.30-11.00$ & Ceramah dan diskusi dampak dan cara \\
& menanggulanginya
\end{tabular}




\begin{tabular}{ll}
\hline Jadwal & Kegiatan \\
& \\
\hline Sesi 3 & Tanya jawab / Kuis dan pemberian bingkisan \\
$11.00-11.40$ & Penutupan \\
$11.40-12.00$ & \\
\hline
\end{tabular}

Adapun yang menjadi peserta kegiatan ini adalah Anak Asuh dari Panti AsuhanPutra Darush sholihin, yang beralamat di Jl. KH. Sholeh Iskandar Kota Bogor, yangberjumlah sekitar 30 orang, dimana secara usia beragam, mulai dari tingkat SDsampai SMA. Pada multi usia seperti ini, kemungkinan aktifitas bullying bisa sajaterjadi, baik secara disengaja maupun tidak disengaja. Kegiatan ceramah dantanya jawab berjalan lancar dengan suasana kondusif, para peserta dengan seriusmengikuti seluruh rangkaian acara dengan baik. Mereka menjadi mengerti apa itu bullying, macam-macam bullying, dan dampak bullying bagi korbannya.

Hasil diskusi diantaranya ditemukan bahwa, ternyata dikalangan mereka sendiri yang bertempat tinggal dilingkungan panti asuhan, beberapa perilaku bullying secara tidak sadar kerap mereka lakukan, diantara yang paling dilakukan adalah bullying verbal seperti mengolok-olok, memanggil teman dengan julukan yang kurang baik, mencela, perilaku jail seperti menyembunyikan sandal teman, mainan bahkan pernah pula dalam bentuk fisik seperti mendorong dan memukul. Niat awalnya memang hanya bercanda, namun kadang menjadi serius dan membuat korban menangis. Setelah pengakuan tersebut, kami menjelaskan bahwa semua bentuk bullying baik hanya sekedar verbal atau kata-kata, harus dijauhkan karena akan berdampak tidak baik bahkan sangat berbahaya bagimental manusia khususnya anak- anak.

Bullying sudah mendapat perhatian yang sangat serius, kita masyarakat juga harus turuntangan dalam melawan bullying. Bullying dapat merusak kepribadian seseorang khususnya pihak korban, ia dapat menjadi frustasi, depresi, malu, merasa tidak mempunyaiteman, yang kemungkinan di masa depan mereka akan sulit bergaul dengan masyarakat karena merasa takut dan menutup diri dari pengaruh luar sehingga merasa kesepian. Kesepian, ketakutan dan tertekan inilah yang pada banyak kasus akhirnya mendorong korban melakukan hal yang tidak diinginkan dapat terjadi seperti bunuh diri. Oleh karena itu melihat dampak yangserius ini, maka sewajarnya jika pihak sekolah, pengelola organisasi seperti panti asuhan, panti yatim, pesantren, pemerintah, dan masyarakat sekitar harus bersama-samamelawan bullying.

Salah satu materi yang kami berikan adalah tentang sikap kita jika ada aktifitas Bullying di sekitar, baik yang menimpa diri sendiri ataupun teman, yang diantaranya adalah:

a. Ceritakan pada orang dewasa yang dapat dipercaya. Ceritakan pada orang tua maupun guru yang memiliki otoritas untuk menindaklanjuti perilaku bullying.

b. Abaikan penindas dan jauhi. Seperti yang disebutkan sebelumnya, penindas akan merasa senang apabila mendapatkan reaksi seperti yang dia inginkan. 
c. Tingkatkan keberanian dan rasa percaya diri. Tunjukkan pada lingkungan sekitar bahwa anda bukan orang yang lemah dan mudah untuk ditindas.

d. Bicara pada pelaku bullying.

e. Tunjukkan bahwa apa yang dilakukan pelaku bukan hal yang baik dan bahkan berbahaya.

f. Bantu teman yang menjadi korban bullying. Jika menyaksikanperilaku bullying, jangan diam saja dan cobalah untuk memberi dukungan padakorban.

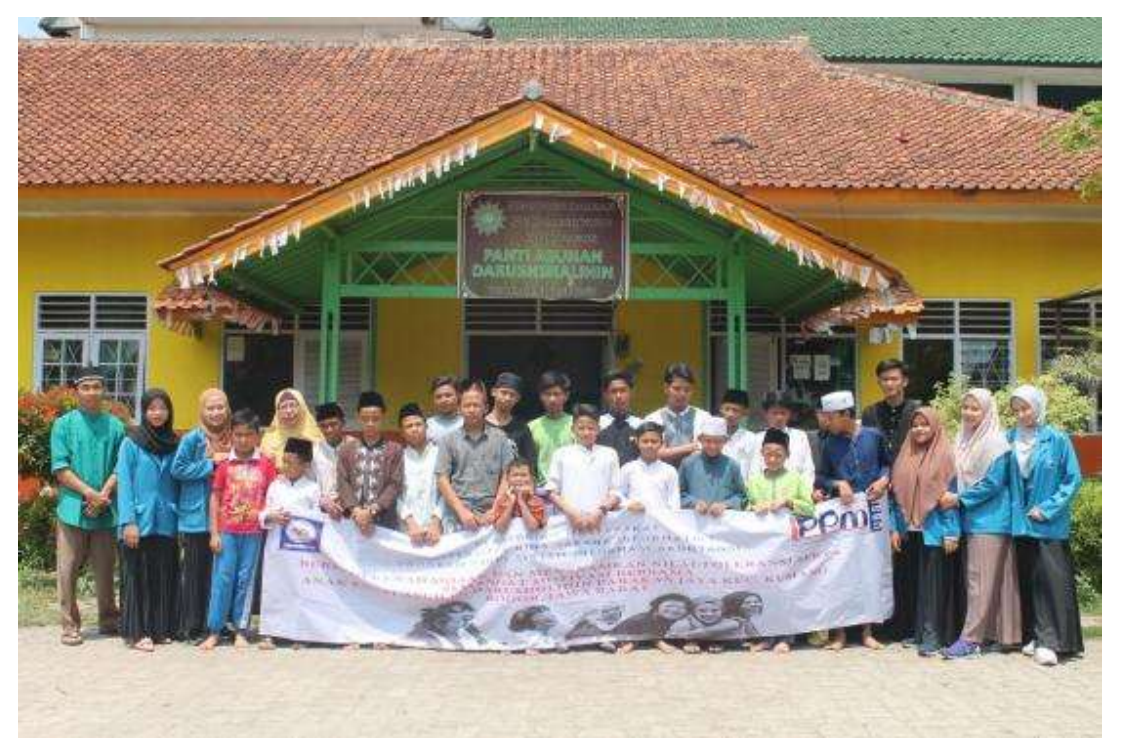

Gambar 1. Foto Kegiatan Sosialisasi pada siswa

Untuk membuat suasana menjadi menarik, beberapa kali kami memutar video terkait beberapa contoh aktifitas bullying, sehingga mereka dengan mudah, mampu mengidentifikasi perilaku yang termasuk pada kategori bullying. Sambil menonton tayangan, merekapun bnayak yang kaget, karena contoh aktifitas bullying ini sering mereka lakukan dan sudah dianggap hal yang biasa, seperti memanggil orangdengan sebutan yang tidak semestinya. Mengetahui bahwa kebiasaan ini ternyata masuk dalam kategori bullying, mereka berjanji untuk mengubahpanggilan tersebut dengan panggilan nama atau panggilan yang lebih baik dan tidak akan mengulaginya di kemudian hari. Kami bersyukur, ternyata anak-anak dipanti ini cukup mengerti materi yang disampaikan dan berharap semoga masalah bullying dalam bentuk apapun dapat diatasi, sehingga setiap orang dapat dengan bebas mengaktualisasikan diri dengan aman dan nyaman tanpa takut adanya penindasan. Diakhir acara kami mengadakan kuis, terkait materi yang telah disampaikan dan memberikan hadiah bagi mereka yang mampu menjawab dengan benar. 


\section{Simpulan dan Rekomendasi}

Beberapa hal yang dapat disimpulkan dari kegiatan Pengabdian KepadaMasyarakat, sebagai berikut:

a. Peserta memahami apa itu bullying dan jenis-jenisnya

b. Peserta menjadi tahu penyebab bullying dari sisi pelaku dan korban

c. Memberikan pengetahuan tentang cara mengatasi bullying

d. Peserta menjadi tahu cara menangani kasus bullying,

e. Mengajak peserta untuk saling menghormati teman, guru dan masyarakat pada umumnya

\section{Acknowledgements}

Terima kasih kepada pengurus Panti Asuhan Putra Darush sholihin, yang beralamat di Jl. KH. Sholeh Iskandar No. 2 Rt 01/04 Parakan Jaya Kemang Bogor, atas dukungan kepada kami dan sudah berusaha memfasilitasi kegiatan pengabdian masyarakat ini

\section{Daftar Pustaka}

Sandri, R. (2015). Perilaku Bullying Pada Remaja Panti Asuhan Ditinjau Dari Kelekatan Dengan Teman Sebaya Dan Harga Diri. Jurnal Psikologi Tabularasa, 10(1),

http://jurnal.unmer.ac.id/index.php/jpt/article/viewFile/242/113

Sari, Y. P., \& Azwar, W. (2018). Fenomena Bullying Siswa: Studi Tentang Motif Perilaku Bullying Siswa di SMP Negeri 01 Painan, Sumatera Barat. Ijtimaiyya: Jurnal Pengembangan Masyarakat Islam, 10(2), 333-367.

https://doi.org/10.24042/ijpmi.v10i2.2366

Shidiqi, M. F., \& Suprapti, V. (2013). Pemaknaan Bullying pada Remaja Penindas ( The Bully ). Jurnal Psikologi Kepribadian Dan Sosial, 2(2), 90-98. http://journal.unair.ac.id/download-fullpapers-jpksd3ed32a0002full.pdf

Yuyarti. (2018). Mengatasi bullying melalui pendidikan karakter. Jurnal Kreatif, 8(2), 168-173.

https://journal.unnes.ac.id/nju/index.php/kreatif/article/viewFile/16506/839 7

Zakiyah, E. Z., Humaedi, S., \& Santoso, M. B. (2017). Faktor Yang Mempengaruhi Remaja Dalam Melakukan Bullying. Prosiding Penelitian Dan Pengabdian Kepada Masyarakat, 4(2), 129-389. https:/ / doi.org/10.24198/jppm.v4i2.14352 